\title{
Contribution of TV Dramas and Movies in Strengthening Sustainable Tourism
}

\author{
Yidi Hua ${ }^{1,2}$, Chompunuch Jittithavorn ${ }^{3}$, Timothy J. Lee ${ }^{4,5}$ and Xiaohua Chen ${ }^{6, *}$ \\ 1 Research Center of Industrial Economy around Hangzhou Bay, Ningbo Polytechnic, Ningbo 315800, China; \\ 2016004@nbpt.edu.cn \\ 2 Institute of Asia and Pacific Studies, University of Nottingham, Ningbo 315400, China \\ 3 Department of Tourism and Hotel Management, University of Phayao, Bangkok 10330, Thailand; \\ chompunuch.ji@up.ac.th \\ 4 Faculty of Hospitality and Tourism Management, Macau University of Science and Technology (MUST), \\ Macao 999078, China; tilee@must.edu.mo \\ 5 Griffith Institute for Tourism (GIFT), Griffith Business School, Griffith University, Brisbane 4111, Australia \\ 6 Graduate School of Hotel \& Tourism, Kyung Hee University, Seoul 02447, Korea \\ * Correspondence: yidingxing@khu.ac.kr; Tel.: +82-2-961-0863
}

Citation: Hua, Y.; Jittithavorn, C.; Lee, T.J.; Chen, X. Contribution of TV Dramas and Movies in Strengthening Sustainable Tourism. Sustainability 2021, 13, 12804. https://doi.org/ $10.3390 /$ su132212804

Academic Editors: Raquel Camprubí and Ariadna Gassiot-Melian

Received: 3 September 2021

Accepted: 12 October 2021

Published: 19 November 2021

Publisher's Note: MDPI stays neutral with regard to jurisdictional claims in published maps and institutional affiliations.

Copyright: (c) 2021 by the authors. Licensee MDPI, Basel, Switzerland. This article is an open access article distributed under the terms and conditions of the Creative Commons Attribution (CC BY) license (https:// creativecommons.org/licenses/by/ $4.0 /)$.

\begin{abstract}
This study aims to (a) identify the relationship between travel motivation and popular media (mainly films or TV programs), (b) examine the relationship between destination images and popular media as an information source, and (c) investigate the influence of popular media on destination's decision-making process. The relationship is focused on three aspects: motivation, destination image, and the decision-making process for tourists. This study employed a self-administered questionnaire survey. The questionnaire was composed of (i) respondents' motivation and general information about their visit to the destination (Jeju Island in Korea), (ii) attributes of the film-induced tourism of their visit to the destination, and (iii) respondents' socio-demographic elements. A correlation analysis and a standard multiple regression analysis were employed. The results discovered that there is a significant relationship (a) between a destination and popular media, (b) between destination image and popular media, and (c) between the decision-making process and popular media. The implications of this study can help destination marketers and managers build competitive strategies using the effective management of film-related tourist attraction sites to increase visitor numbers and ensure that a sustainable long-term relationship is encouraged between destinations and tourists.
\end{abstract}

Keywords: tourist destination; destination image; TV dramas; travel motivation; decision-making process

\section{Introduction}

Tourist attractions are often introduced through media such as television and films that are not directly connected with tourism marketing activities or promotion [1,2]. Going to the cinema and watching television are common leisure activities undertaken by most people on a global scale $[3,4]$. Popular media are accessible sources of entertainment, pleasure, fantasy, and joy and lead to improved understanding of the world [5-7]. Tourism is often understood to exchange and interact in expectations, dreams, images and fantasies [8,9]; destination image and media representations play an important role in influencing holiday decision making [3,10-12].

Popular media (film, television, magazines, and literature) can help to create and sustain people's anticipation and imagination of the sights and scenes that they would enjoy during travel $[3,13,14]$. Imagination is a central notion connecting media and tourism, arguing that the media plays a significant role in facilitating certain emotions and stimulating the imagination, which may eventually translate into travel activity $[15,16]$. This realization has led to a classification of a new type of tourism called "film-induced tourism" [1,7,17]. 
Film is an innovative way for destinations to be promoted to prospective visitors, and it is a marketing tool that has proved successful for several destinations [18]. It is a form of non-paid advertising that can create a major level of awareness and demand for a tourist destination $[10,19]$.

Therefore, the consumption of television and film has a significant influence on tourism destination and tourist attraction marketing [6]. This study analyzes how destination image is related to media focusing on films and TV programs [20,21]. Jeju Island in South Korea was selected as the focused study site, and the way that film and TV programs can contribute for effective destination marketing was investigated. The study has the following three objectives: (a) to identify the relationship between travel motivation and popular media (mainly films or TV programs); (b) to examine the relationship between destination images and popular media as an information source; (c) to investigate the influence of popular media on destination's decision-making process. It amplifies the significance of the role of TV programs for destination image and provides potential niche strategies to maximize its roles.

While most previous studies in this field worldwide have focused on attracting international tourists using movie-famous spots and regions $[7,13,15,16]$, the current study investigates those domestic tourists who are affected by many potential destinations shown in popular mass media programs. The current study sheds valuable light on the direction of sustainable and strategic approaches by segmenting different market types. It also deeply searches for the strategic decision process, which is not often addressed in discussions about movie tourism. As a result, the study presents unique messages by filling the gap in academic discussions and makes insightful recommendations to maximize the advantages of film-induced tourism resources.

\section{Literature Review}

\subsection{Film-Induced Tourism as a Destination Marketing Tool}

One of the special-interest tourism trends based on visiting destinations is traveling to where a TV drama series or film was filmed, and it has been widely called "movie-induced tourism" [15,22]. This term is understood as the tourism that follows the success of a film or series in the place where it was filmed [18]. This typology arose in the late 1990s due to tourists' specific interest in searching for where their favorite film was filmed. The "movieinduced tourism" as an emerging tourism product should be recognized as a typology of popular cultural tourism, as it responds to a phenomenon often caused by the commercial success of films or TV series [14].

Tourists' actual visit to a tourism destination creates a more realistic image than one developed indirectly [18]. Initial opinions are the result of images seen on film, but after the visit, a more accurate opinion can be formed [23]. The post-tourist experience is created through a series of "framed images", ranging from what is seen from the coach window or through the camera lens or on the TV screen [6,14]. Destination image is not only grounded on interpretation of visual and/or verbal information, it also contains histories, biases, fantasies, assumptions, prejudices, preconceptions and factual stories [24]. Marketing literature confirmed a solid link between film-induced tourism and destination as a product $[16,17,25]$. The goal of film in a tourism destination is to positively portray a destination [4]. The exposure that film offers a destination (e.g., city, province or country) is an advertisement viewed by potentially millions of people who cannot be reached through conventional tourism promotions $[10,26]$.

Films and TV programs can have a greater power to increase interest in visiting a destination than traditional tourism promotion sources [1,27]. The growth in this alternate type of promotion has been encouraged by the decreasing effectiveness of traditional advertising methods [28], and marketers realize that communication techniques using destination marketing can be more effective, more targeted, more sophisticated, and more widespread [16]. A simple visual placement in the backdrop may be as effective as a highly integrated placement [7]. 


\subsection{Impact of Films or TV Programs for a Tourist Destination}

Researchers have argued about the power that visual media has on the promotion of certain locations $[1,3,29]$. One of the characteristics of film-induced tourism is that TV repeats, DVD products and releases of pre-recorded videos constantly generate new viewers [8]. That is, scenes and images in films and TV programs have the potential to endure for many years $[4,13]$. Additionally, because of increasing high credibility and accessibility, films and TV can increase in significance [5]. However, there are also problems with film-induced tourism. The filmed places usually benefit from film-induced tourism only if the film is successful or receiving recognition from markets [12,27]. In general, film producers have little interest in the influence of their film on tourism and there is no direct concern with long-term influences when selecting film location [1].

Kim, Agrusa, Lee, and Chon [30] suggest that the impacts of film-induced tourism can be categorized into four groups: (i) the economic impact; (ii) enhancement of intangible value in the host community; (iii) negative impacts; and (iv) the perspective of postmodernism. There are a number of studies on the economic influence on the tourist destination $[1,4,31,32]$. Film and TV can have a positive influence on the tourism industry of the destination [13], and an increase in visitor numbers generally benefits the local economy [1]. Both film and TV have a wide socio-economic appeal, leading to expand the visitor market base $[16,21]$. Another benefit of film tourism is that it can be sustainable as a film continues to attract new tourist's year after year [7]. Although the peak of interest comes after a film is released, a $54 \%$ increase was still apparent at least five years later in the 12 films studied [33].

Studies have shown that films or TV programs offer a local community or country intangible benefits such as image enhancement or improved level of awareness of a destination [2]. TV is one of the most popular and influential vehicles for drawing attention to destinations [7]. Popular TV series occur every week and offer regular exposure to the destination, creating top-of-mind awareness [12]. The American TV series Lost was filmed on the Hawaiian island of Oahu and led to USD 161 million in production revenue in 2004 [30]. However, negative impacts can occur, such as increased vehicle and pedestrian traffic. Riley and colleagues [33] point to exploitation, locals' imitation of tourists, satisfaction level degradation, increased prices, over-commercialization and loss of privacy, and damage of local facilities. Connell [32] mentioned commercialization and the shortage of existing businesses that can cater to the tourism market. Occasionally, once the TV series ends or the film leaves circulation, the number of visitors can fall dramatically, which conflicts with the notion of sustainable tourism [18]. Unplanned tourism growth results can lead to the ousting of traditional visitors to the destination [14]. In addition, the destruction of the natural environment becomes a problem [34]. For instance, the film The Beach caused massive environmental damage to Phi Phi Lae Island in Southern Thailand [12] from the huge increase in tourists induced by it.

The last direction of the influence of film-induced tourism is post-modern society. The space deconstruction by film or TV and its reconstruction occurs as a post-tourist experience at a boundary between authentic and unauthentic worlds [21]. The hyperreality that predominates media encourages viewers to accept historic events and scenes as featured in films and TV [16]. People tend to rely on the media to signify reality, the media representations come closer to people's expectations of reality, and the reality is a representation itself [6]. Nostalgia as a characteristic of post-modernism plays a role in extending to nostalgia-induced tourism $[4,10]$. The concept of nostalgia in tourism is also supported by those who warned of the potential conservative function of tourist nostalgia and commodification of the past [35]. One of the typical cases of nostalgia-induced tourism can be the Korean drama Winter Sonata, which is a love story between young people. Because the love among youth is largely pure, it encourages TV viewers to remember their youth or first romance. 


\subsection{Tourism Destination Image and Film-Induced Tourism}

Tourist destination image is commonly described as not only the perceptions of individual destination attributes but also the holistic impression made by the destination [18]. Iwashita [17] understands the term "tourist destination image" as the expression of knowledge, impressions, prejudice, imaginations, and emotional thoughts that a person or a group judge on a specific object or place. Hosany, Ekinci, and Uysal [36] suggest that destination image consists of two constructs: cognitive and affective. The cognitive construct can be regarded as beliefs and knowledge about the physical destination, while the affective one refers to the affective quality of feelings toward the attributes and the surrounding environments [37]. Meanwhile, the conative image is analogous to behavior because of the intent or action component. Conation may be regarded as the likelihood of traveling to a destination within a certain time [38].

The idea that a destination image evolves at two levels, the organic and the induced, is proposed [21,39]. The organic image refers to the overall knowledge or perception that one already holds about a location, and it is composed of the information that has not been intentionally directed by promotion or advertising. The information comes from various sources such as newspapers and magazines, history books, travel guides, and the opinion of others $[7,11]$. When combined, all this information provides individuals with a picture of a place. This picture may be the motive for someone to visit the destination. The organic image may be the most powerful factor in destination choice.

Conversely, the intended and planned strategic promotion of tourist destination creates the induced image: paid advertising, publicity, public relations, and incentives. Creating an image for a destination is not an easy task [3,37]. Images come from controlled and direct marketing initiatives by tourism organizations and indirectly from other sources such as films and TV programs. A destination should be favorably differentiated from its competitors and positively positioned in the minds of consumers $[6,10]$. Tourist destinations are not only defined in terms of their physical and geographical elements but also by their symbolic significance $[38,40]$. Any destination can be intentionally made by people and society to carry associations, meanings, values and images that are unique and significant to visitors [7]. What makes locations significant or different is the way in which people look at them and what meanings they derive from or ascribe to them [17,41].

Destinations seen in films or TV programs have obtained iconic status, such as swinging London, romantic Paris, hippie San Francisco, and gritty but sophisticated New York [6]. Some studies have attempted to deconstruct the image development process related with tourism promotion and destination decisions [28,40,41]. Destination image is regarded as a major element of the travel process regarding its influence on general tourist behavior and the decision-making process $[13,15,35]$. In the case of New Zealand, the improvement of the country's image due to a series of movies changed travel behavior, with visitors saying that they played an important role in their decision to visit $[9,11,26]$. However, this type of image making can be subjectively perceived by different people and different personal impressions on each film [16].

\subsection{Film-Induced Tourism and the Decision-Making Process}

The impact of media on the travel decision-making process has been steadily investigated by researchers $[3,7,11]$, who have suggested that consumers receive information about potential destinations via various media sources. This information enables the consumer to construct their own interpretations or images that form the basis of their destination choices [21]. Films have the potential to be more influential than printed materials since they are perceived to have higher level of credibility and not to carry the same bias as printed promotional sources [6].

Purchase decisions of tourists are influenced by product performance characteristics as well as by traveler perceptions [4]. Tourists select one destination over another only when its positive image exceeds its negative one [8]. The visual media may cause anticipations and allurements that attract people to visit $[16,18]$. However, films portray both positive 
and negative images of a destination, and since bad reputation can influence faster than good reputation, marketers should be innovative and use the publicity generated by a film to present their location in the best manner. A film may awaken the curiosity of the audience to find out where the movie was filmed. This is the part of the information seeking stage of the decision-making process that Kotler [42] has outlined. There are five stages listed in the study: (i) need recognition, (ii) information search, (iii) evaluation of alternatives, (iv) selection of product or service, and (v) post-purchase evaluation:

\subsubsection{Need Recognition}

In the tourism literature, need recognition covers the customer's need for a holiday. Films and TV programs suggest to the viewer the need for a place or activity [12]. The need is not perceived in the general sense of "needing a holiday" but is rather perceived as "needing to visit $X$ ", which presents one or more specific locations identified by the customer from media.

\subsubsection{Information Search}

The decision makers act upon their image, beliefs and perceptions of the destination rather than their objective reality of it, which also includes the value-expressive or personality-related attributes of the tourism product [43]. Therefore, destination marketers need to concentrate on both the functional and symbolic attributes of the destination [44]. The media has become a key factor in awareness and style of leadership, causing interest in many remote natural environments in millions of people. By being exposed to these environments, the desire to see and experience becomes much stronger [7].

\subsubsection{Evaluation of Alternatives}

A person may focus on details of price, date, accommodation quality, and mode of transportation to compare destinations [18].

\subsubsection{Purchase and Post-Purchase Behavior}

A movie's success and the efforts of destination marketers cannot always be directly related to the tourism effects, as there are many inputs to the decision to travel, which may or may not be connected directly to the consumption of movies or TV programs [23]. Film and television producers as well as tourists are a target business market for destinations $[16,45]$.

\subsection{Jeju Island in South Korea as a Destination Partly Created by Film-Induced Tourism}

Jeju Island is the largest island in South Korea, and the island boasts not only mild weather but also different types of beautiful scenery (cliffs, caves, beaches, and waterfalls) to tourists. The top visitor places include: Seongsan Ilchulbong Sunrise Peak with spectacular views, Hallasan Mountain National Park with diverse species of flora and fauna, and Manjanggul Cave, which is the world's longest lava tube, registered in the UNESCO World Natural Heritage Site $[46,47]$. Meanwhile, Jeju recently won the Global Geopark Certificate and has been selected as one of "the New 7 Wonders of Nature" [47]. Due to these attractive sources for tourism and entertainment, Jeju Island has been featured in several famous movies and TV dramas since 2000, mainly including Swiri, All-in, Daejanggeum, The destiny, and Emergency landing of love [48].

There are differences in the image of the Jeju islands as depicted before and after 2000. Before 2000, Jeju's image was as a location for history and honeymoon, and after 2000, it was as a place for romantic memories and dreams, and for the natural environment. All-in was a drama that aired in 2003 with Jeju Island as a backdrop. It was a huge hit program attracting about $40 \%$ of viewers between January and April in 2003 . This drama was filmed in Seopjikoji Cape, on the way to Seongsan Ilchulbong Sunrise Peak. Before the release of the drama, the location had few tourists, but after it, tourist numbers sharply increased. Seopjikoji Cape became, by far, the most famous destination for tourists in the island at that time. The drama was also filmed in other famous attractions: Jungmun Beach Golf 
Club, Jeju L hotel, Jeju S hotel, Jeju H hotel, and the Jeju Convention Centre. The success of the drama led to positive economic effects and positive images across the island. However, there are some negative results, such as a rapidly growing number of shops, which make the locations over-crowded and over-commercialized [48,49].

In addition, the Korean Wave (Hallyu) is an increase in global popularity of South Korean culture since the 1980s. First driven by the spread of K-dramas and K-pop across Asia during its initial stages, the Korean Wave evolved from a regional development into a global phenomenon, carried by the Internet and social media and the proliferation of K-pop music videos on YouTube. The popularity of Jeju as a strong media-induced tourism destination has also been accelerated by the development of Korean Wave [46,49]. There are arguments related to the current COVID-19 pandemic in the general tourism destination development and media tourism [50,51]. Site closures and other effects of the ongoing COVID-19 pandemic present additional challenges for film-induced tourism destinations worldwide [52], but the current study mainly discusses the theoretical arguments about the impact and contribution of the places promoted to potential tourists through popular media such as TV dramas or movies.

\subsection{Hypotheses Development}

Targeting Jeju Island, South Korea, the following hypotheses were framed: Hypothesis 1 (Motivation):

Hypothesis 1a (H1a). There is no significant relationship between motivation and destination through films or TV programs.

Hypothesis $\mathbf{1 b}(\mathbf{H} 1 \mathbf{b})$. There is a significant relationship between motivation and destination through films or TV programs.

Hypothesis 2 (Destination image):

Hypothesis 2a (H2a). There is no relationship between destination image and destination through films or TV programs.

Hypothesis $\mathbf{2 b} \mathbf{b} \mathbf{H} \mathbf{2} \mathbf{b})$. There is a significant relationship between destination image and destination through films or TV programs.

Hypothesis 3 (Decision-making process):

Hypothesis 3a (H3a). There is no influence of films or TV programs on the decision-making process.

Hypothesis $\mathbf{3 b} \mathbf{b} \mathbf{H} \mathbf{3} \mathbf{b})$. There is a significant influence from films or TV programs on the decisionmaking process.

\section{Methodology}

\section{Data Collection and Analysis}

This study employed a self-administered questionnaire survey, which was composed of three parts. Part I asked about respondents' travel to the destination, with questions such as, "what is the primary purpose of your current visit to Jeju Island?" Part II measured the attributes of film-induced tourism of Jeju Island such as motivation, image, decisionmaking process and media as decided by previous studies. Part III consisted of sociodemographic elements such as age, gender, and marital status. The questionnaire was designed and distributed in Korean, as the respondents were Koreans, and it was translated into English by the authors of the current study. Table 1 presents the original sources for the questionnaire items of the current study. 
Table 1. Original sources for the questionnaire items.

\begin{tabular}{|c|c|c|}
\hline Variables & Items & Source \\
\hline Travel characteristics & $\begin{array}{c}\text { What is the primary purpose of your current visit to Jeju Island? } \\
\text { How many times have you visited in Jeju Island? } \\
\text { What was your info source(s) in planning a trip to Jeju Island? } \\
\text { Which place did you most want to visit in Jeju Island? } \\
\text { How many times did you watch a movie/TV program about Jeju Island? } \\
\text { What did you most expect from a movie/TV program about Jeju Island? } \\
\text { How was your experience on the trip to the locations in Jeju Island of a movie or TV program? }\end{array}$ & Im and Chon [25] \\
\hline Motivation & $\begin{array}{l}\text { Scenery and Landscape. } \\
\text { The cultural attraction of the destination. } \\
\text { The storyline or plot of a film or TV program. } \\
\text { The experiences of people in a film or TV program. } \\
\text { The romance and adventure in a film or TV program. } \\
\text { The actors in a film or TV program. } \\
\text { The characters portrayed by the actors. }\end{array}$ & $\begin{array}{c}\text { Hudson, Wang, and } \\
\text { Gil [10] }\end{array}$ \\
\hline $\begin{array}{l}\text { Destination } \\
\text { image }\end{array}$ & $\begin{array}{c}\text { It is generally a safe place to visit. } \\
\text { There is a high standard of living. } \\
\text { Local standards of cleanliness and hygiene are high. } \\
\text { Roads are in good condition. } \\
\text { Good quality restaurants and hotels are easy to find. } \\
\text { Everything is different and fascination. } \\
\text { There are many places of interest to visit. } \\
\text { Good destination for an educational or learning experience. } \\
\text { Many places of historical or archaeological interest. } \\
\text { Many opportunities to see interesting local festivals. } \\
\text { Restful and relaxing place to visit. } \\
\text { Offers a lot in terms of natural scenic beauty. } \\
\text { Has pleasant weather. } \\
\text { Mandant number of nature's preserves and wilderness areas. } \\
\text { Many packaged vacations available. } \\
\text { Good tourist information is readily available. } \\
\text { Tours and excursions are readily available. } \\
\text { Tourist attractions are well known and famous. } \\
\text { Prices are low. } \\
\text { Goods and services are affordable. }\end{array}$ & $\begin{array}{c}\text { Hudson, Wang, and } \\
\text { Gil [10]; } \\
\text { Iordanova and } \\
\text { Stylidis [35] }\end{array}$ \\
\hline
\end{tabular}

\section{Decision-making process}

After watching a movie or TV program, I have always wanted to visit the locations where a movie was filmed.

A movie or TV program has influenced me to visit Jeju Island.

Once I had seen a movie or TV program, I had to come to Jeju Island.

A movie or TV program increased my interest in a future revisit to Jeju Island.

I am interested in a destination featured in a film or TV Program.

After watching a film or TV product, I think visiting a

destination featured in a film or TV program.

Media

Advertising a destination through a film or TV program $t$ is more effective method than newspaper or magazine.

A destination in a film or TV program is one of the advertising methods for tourism.

A destination in a film or TV program is impressive.

A destination in a film or TV program is good method for advertising.

I frequently watch the destination that is displayed in a film or TV program through the media.

The survey was conducted by the authors, with six master's degree students majoring in tourism studies and four non-students as assistants. After conducting a pilot study, modifications in presentations and content were made to improve it. The final questionnaire was administered at the check-in areas of Gimpo Airport in Seoul, Korea for a week in August 2019. The researchers randomly approached passengers from 7 a.m. to 5 p.m. (while they were in the queue for check-in or after check-in but before they entered the boarding gate in the airport), explained the research project, and gave the printed copy of questionnaires and a pen for filling out only those who gave consent. The researchers stood by them to offer additional guidance if necessary. The Gimpo to Jeju route is the most popular domestic flying route in South Korea, which is 50 min one way.

Korean passengers flying to Jeju Island who were 18 years of age or older were randomly invited to participate. Those who lived in Jeju Island were excluded from the 
survey to secure objectivity and reliability. It took around ten minutes to complete a questionnaire per respondent, and a small gift was given as a token of appreciation after they were completed. Out of the 250 questionnaires distributed in total, 213 were used for the analysis after removing incomplete ones. The answers were coded and placed into PASW 18.0 software, and the goodness of fit of the data was evaluated. Descriptive statistics were used for the measure of central tendency (mean, mode, median) and the measure of dispersion (standard deviation, inter-quartile range, and variance).

\section{Analysis}

\subsection{Descriptive Statistics}

As seen in Table 2, 116 (54.5\%) respondents were female and 97 (45.5\%) males. More were married or living with a partner (56.3\%) than single $(43.7 \%)$. The largest age group was 25 to 34 years (42.7\%), followed by 35 to 44 years (34.7\%), and 45 to 54 years (12.2\%). With respect to employment status, most of them were full- or part-time employees (46.5\%), or self-employed (27.2\%). Eighty-three respondents (39\%) had gained an undergraduate degree and 65 (30.5\%) junior college or vocational school. As for the level of annual income, $36.6 \%$ of them earned USD 80,001 to 100,000 , while USD 60,001 to 80,000 was earned by $22.5 \%$.

Table 2. Demographic characteristics of respondents $(n=213)$.

\begin{tabular}{|c|c|c|}
\hline Variables & Frequency & Percentage (\%) \\
\hline \multicolumn{3}{|l|}{ Gender } \\
\hline Female & 116 & 54.5 \\
\hline Male & 97 & 45.5 \\
\hline \multicolumn{3}{|l|}{ Marital States } \\
\hline Single & 93 & 43.7 \\
\hline Married & 120 & 56.3 \\
\hline \multicolumn{3}{|l|}{ Age } \\
\hline $18-24$ & 8 & 3.8 \\
\hline $25-34$ & 91 & 42.7 \\
\hline $35-44$ & 74 & 34.7 \\
\hline $45-54$ & 26 & 12.2 \\
\hline $55-64$ & 11 & 5.2 \\
\hline 65 or older & 3 & 1.4 \\
\hline \multicolumn{3}{|l|}{ Employment status } \\
\hline Full or part time employee & 99 & 46.5 \\
\hline Professional (doctor, lawyer, etc.) & 14 & 6.6 \\
\hline Self-employed & 58 & 27.2 \\
\hline Public officer & 8 & 3.8 \\
\hline Housewife & 30 & 14.1 \\
\hline Student & 4 & 1.9 \\
\hline \multicolumn{3}{|l|}{ Education } \\
\hline Junior high school & 8 & 3.8 \\
\hline High school & 45 & 21.1 \\
\hline Junior college/vocational school & 65 & 30.5 \\
\hline Undergraduate degree & 83 & 39.0 \\
\hline Postgraduate degree & 12 & 5.6 \\
\hline \multicolumn{3}{|l|}{ Annual household income (US Dollar) } \\
\hline Up to 60,000 & 17 & 8.0 \\
\hline 60,001 to 80,000 & 48 & 22.5 \\
\hline 80,001 to 100,000 & 78 & 36.6 \\
\hline 100,001 to 120,000 & 41 & 19.2 \\
\hline More than 120,000 & 29 & 13.6 \\
\hline
\end{tabular}

The behavior characteristics of the respondents are summarized in Table 3. On information sources, $38 \%$ of tourists gained information through the Internet and media (18.8\%), and travel agencies (16\%). Walking the Olleh hiking streets (walking along the natural narrow walking paths dividing different farmers areas) was most popular, and around 70\% of respondents visited Jeju once or twice to do this. The most common activity visitors 
expected during their trip was "to visit places displayed in the media" (48.8\%), and "to experience the same feelings in person as through the media" $(32.9 \%)$. This means that more than $80 \%$ of the respondents traveled to Jeju Island mainly motivated by popular media such as films or TV programs showing wonderful beaches or attractive places that can be found only in Jeju Island. Finally, with respect to differences between expectation and real experience of visiting the island, $70 \%$ of visitors felt that there was no difference.

Table 3. Tourist behavior characteristics $(n=213)$.

\begin{tabular}{cccc}
\hline & Variables & Frequency & Percentage (\%) \\
\hline Purpose of visit & Vacation & 126 & \\
& Friend \& Relative & 33 & 59.2 \\
Conference \& Meeting & 25 & 15.5 \\
Media (TV, film, etc.) & 19 & 11.7 \\
& Others & 10 & 8.9 \\
\hline
\end{tabular}

Number of visiting Jeju (excluding this time, in your

lifetime)

\begin{tabular}{|c|c|c|}
\hline Never & 7 & 3.3 \\
\hline Once & 84 & 39.4 \\
\hline Twice & 67 & 31.5 \\
\hline Three times & 33 & 15.5 \\
\hline Four times or more & 22 & 10.3 \\
\hline \multicolumn{3}{|l|}{ Source of information } \\
\hline Media (TV, film, etc.) & 40 & 18.8 \\
\hline Travel agency & 34 & 16.0 \\
\hline Travel magazine/brochure & 19 & 8.9 \\
\hline Internet & 81 & 38.0 \\
\hline Recommendation & 31 & 14.6 \\
\hline Others & 8 & 3.8 \\
\hline \multicolumn{3}{|l|}{ Places want to visit } \\
\hline Hallasan Mountain National Park & 43 & 20.2 \\
\hline Olleh Hiking streets & 85 & 39.9 \\
\hline Seongsan Sunrise Peak & 29 & 13.6 \\
\hline Seopjikoji Cape & 39 & 18.3 \\
\hline Manjanggul Cave & 4 & 1.9 \\
\hline Park Southern Land & 13 & 6.1 \\
\hline \multicolumn{3}{|l|}{$\begin{array}{l}\text { Number of watching Jeju from media (in your } \\
\text { lifetime) }\end{array}$} \\
\hline 1 to 3 times & 33 & 15.5 \\
\hline 4 to 6 times & 52 & 24.4 \\
\hline 7 to 9 times & 44 & 20.7 \\
\hline 10 times or more & 84 & 39.4 \\
\hline \multicolumn{3}{|l|}{ Expecting activities from media } \\
\hline To visit a place seen in media & 104 & 48.8 \\
\hline To experience the same feelings & 70 & 32.9 \\
\hline To know how local people live & 5 & 2.3 \\
\hline To buy souvenirs & 21 & 9.9 \\
\hline Others & 13 & 6.1 \\
\hline \multicolumn{3}{|l|}{ Difference between expectation and experience } \\
\hline Below expectation & 27 & 12.7 \\
\hline The same as expected & 149 & 70.0 \\
\hline Above expectation & 37 & 17.4 \\
\hline
\end{tabular}

As shown in Table 4, the mean score of the image effect was 71.2 and that of the decision-making process was 13.4. The decision-making process showed the largest neg- 
ative skewness $(-0.415)$. The image displayed a slight positive kurtosis, indicating a relatively peaked distribution.

Table 4. Descriptive statistics.

\begin{tabular}{|c|c|c|c|c|c|c|c|c|c|}
\hline & \multirow[t]{2}{*}{$\mathbf{N}$} & \multirow[t]{2}{*}{ Minimum } & \multirow[t]{2}{*}{ Maximum } & \multirow[t]{2}{*}{ Mean } & \multirow[t]{2}{*}{ Std. Deviation } & \multicolumn{2}{|c|}{ Skewness } & \multicolumn{2}{|c|}{ Kurtosis } \\
\hline & & & & & & Statistic & Std. Error & Statistic & Std. Error \\
\hline Motivation & 213 & 15.00 & 35.00 & 23.9765 & 4.31697 & 0.339 & 0.167 & -0.268 & 0.332 \\
\hline Image & 213 & 45.00 & 100.00 & 71.2254 & 10.49690 & 0.115 & 0.167 & 0.163 & 0.332 \\
\hline Decision-making & 213 & 4.00 & 20.00 & 13.4319 & 3.64476 & -0.415 & 0.167 & -0.214 & 0.332 \\
\hline Valid N (listwise) & 213 & & & & & & & & \\
\hline
\end{tabular}

\subsection{Hypotheses Testing}

Correlation analysis and standard multiple regression between variables are widely used to test the hypotheses. Correlation can be examined by Pearson correlation coefficient $(\gamma)$ or Spearman's Rank Order Correlation. Both values are used to assess the relationship's strength and direction [53]. In the current study, Pearson's correlation coefficients $(\gamma)$ were employed to evaluate the hypotheses as the distribution is not normal. The sign in front of the values indicates the relationships' direction and the size of the coefficient indicates the strength of the relationship [54].

Hypothesis 1 (Motivation)

Regarding the relationship between motivation and destination through films or TV programs, Pearson's value suggests that the relationship between motivation and media is positive, and a value of 0.485 shows a medium relationship between them. Thus, the alternative hypothesis is accepted, and the null hypothesis is rejected. There is a significant relationship between them, and we can be confident about the collected results.

Hypothesis 2 (Destination Image)

In terms of the relationship between destination image and destination through films or TV programs, Pearson's correlation indicates a positive and strong relationship (0.613) between them. Thus, $\mathrm{H} 2 \mathrm{~b}$ is accepted and $\mathrm{H} 2 \mathrm{a}$ is rejected. We can be confident about the analyzed results. Looking at the standard multiple regressions, the influence of media is predicted by destination image.

Hypothesis 3 (Decision-making process)

In regard to the relationship between decision-making process and media, the number is accurate with no missing data. Pearson's correlation indicates a positive and strong relationship (0.819) between them. Therefore, H3b is accepted and H3a rejected. Furthermore, there is a significant relationship between them, and it can be considered that the gathered results are reliable. Table 5 provides a summary of the testing results for all three hypotheses.

Table 5. Summary of the hypotheses test results.

\begin{tabular}{ccc}
\hline & \multicolumn{2}{c}{ Hypotheses Testing for Relationships } \\
\cline { 2 - 3 } & Variables & Score and Strength of the Relationship \\
\hline Hypothesis 1 & Motivation-Media & Medium relationship (0.485) \\
Hypothesis 2 & Destination Image-Media & Strong relationship (0.613) \\
Hypothesis 3 & Decision-making process-Media & Strong relationship (0.819) \\
\hline
\end{tabular}

\section{Conclusions}

\subsection{Discussion and Theoretical Contributions}

The consumption of television and film is widely recognized to have a strong and impressive power and influence on tourism destination image. This current study analyzed how the image of a tourist destination is related to media focusing on films and TV programs. The study setting was Jeju Island, South Korea, and the study looked at how film and TV programs can contribute to effective destination marketing. The study was 
focused on the relationship between a destination and popular media such as films and TV programs. The results from the analysis provided evidence that the relationship between the two constructs (destination and media) is acceptable. There is a positive relationship between motivation and media, implying that viewers who watch TV or films may consider visiting a featured destination.

The current study delivers unique findings in respect of film-induced tourism. First, most of the prior studies in film-induced or media tourism discussed the holistic national image of a destination, mainly to attract more international tourists. However, the current study was focused on domestic tourism destinations and is aimed at attracting domestic tourists. A successful domestic tourism destination can provide a grassroot opportunity to develop successful international tourism; thus, this study provides a valuable possibility on how a local film-induced tourism destination can attract people live in populous urban areas in the same country and eventually from overseas.

Second, the current study focused on a small rural area rather than internationally well-known large cities or destinations. It contributed to small remote area analyses by showing a strategic pathway that they can and should focus on to attract tourists who can help develop their local economy. Third, the results confirmed that the positive portrayal of a destination in a TV series can affect the image and maintain it through repeat viewing. Films and TV programs can attract audiences not only because of attractive physical properties (scenery or landscape) but by their related storylines, themes, characters and events, stimulating people's emotions, feelings and attitudes toward destinations. Filmrelated promotion can be one of the most effective ways for reinforcing tourist awareness since it shows product features and builds a destination's visual image [18].

Fourth, there is a positive relationship between the decision-making process and media. Meanwhile, the aim of destinations in performance marketing is to draw visitors by influencing their travel decision-making process. A powerful factor in this procedure is the role played by strategic use of visual media, and film reinforces destination awareness and affects the decision-making process.

Finally, while a general film-induced tourist is possibly more strongly attracted by the novelty, a serendipitous type of film-induced tourist may travel to a film place. It is also noteworthy that viewers may associate their emotions with the film context, such as imagining themselves in the same situation as the main characters. The storylines, famous film actors and technology effects may strongly influence audiences' virtual experiences of destinations, and then their visits to the film locations. Therefore, film-induced tourism can be driven with various themes, such as romance, history, science fiction, fantasy, action, and even education. In summary, the findings in the current study indicate that there is a significant relationship between a destination and popular media, implying that a positive and attractive image through popular media encourages viewers to visit a destination.

\subsection{Practical Implications}

This study amplifies the idea that films have significant power in influencing people about which destination they wish to visit and generally enhances a destination's image. The study focused on Jeju Island, South Korea, and the results support the hypotheses about the relationship between a destination and media. The current study delivers valuable and practical messages for film-induced tourism practitioners.

First, Jeju Island has been presented by many popular TV programs and films, but if a film portrays a negative image, it may lead to poor opinions of the destination. Therefore, destination marketing organizations should take care of this issue by either trying to eliminate or reduce the negative image or by taking advantage of the positive publicity of the films. All of these should be performed under a coordinated marketing strategy for a destination.

Second, the current study has provided insight into the impacts of media on a destination through empirical identification of the relationship between a destination and media. The results can assist practitioners to develop the relationship further and assist destination 
marketers to identify film-induced tourism as well as to plan competitive strategies to assure long-term relationships between destinations and visitors.

Third, the results also imply that media may only be considered as a supplementary motivation, not a main motivation for visiting specific locations. It seems that film-induced tourism tends to be a serendipitous tourist activity. Therefore, effective promotion, packaging, and strategic segmented marketing with different target marketing for differentiated target markets needs to be implemented to create a potentially lucrative market segment. For example, the promotion activities for attracting tourists can be segmented by age group, origin of residence, purpose of visit, and main activities in a destination for more strategic and efficient marketing activities. Film-induced tourism has the strong power to offer destinations, significantly increased tourist awareness, and potential visitation, which in turn can stimulate increased economic development for a destination.

Fourth, another important aspect of the marketing activities is the collaboration of authorities at the destination and the production. Collaborative and integrated campaigns with the overall film-related industry can be a powerful pathway to induce film tourists. The categorization of film-induced tourism can assist in the development of a fully targeted marketing strategy for the destination. Destination marketing organizations (DMO) should expand the promotional tools that use films to attract tourists. Film directors or producers should be treated as prospective visitors and special visits for them should be organized. As a negative image may be damaging, DMO should be responsible for maintaining the positive image of the destination focusing on the publicity of the film or on publicity that can be created due to a film. In addition, movie maps should be published and distributed in the popular tourist areas of such destinations.

Finally, there is a strategic need to develop less popular areas of Jeju Island to effectively promote the island for diverse types of potential film-induced tourists. Although the current study only focused on a media tourism destination in a certain part of Korea, the implications from the study can be applied to many other destinations in different countries, especially where they have an interest in developing their destination as a lucrative location using the advantages of film-induced tourism.

\subsection{Limitations and Further Research}

Although this study provides theoretical contributions and managerial implications noted above, there are limitations that influence the results. First, a larger sample size would result in more reliable results. Second, the questionnaire was collected during the off-peak season and thus destination perceptions may be different to those of the peak season. Third, this study was a preliminary one that concentrated on the relationship between a destination and the media. Finally, the study was restricted in the choice of observed variables, and there may be other variables (i.e., individual characteristics, type of movie) that can provide deeper insights into film-induced tourism. Further study of the role of films in the decision-making process for tourists in other locations in Korea or overseas countries would also provide insightful comparative studies. As this study heavily concentrated on domestic Koreans and those who have been to Jeju Island, comparing Koreans and foreigners and people who have never been to the island would be valuable.

Author Contributions: Conceptualization, Y.H.; methodology, C.J.; validation, X.C.; writingoriginal draft preparation, Y.H. and C.J. writing-review and editing, T.J.L. and X.C.; supervision, T.J.L.; funding acquisition, Y.H. and X.C. All authors have read and agreed to the published version of the manuscript.

Funding: This paper was supported by Ningbo Polytechnic Research Fund in 2021. (grant number: NZ21C004). This paper was supported by the China Sponsorship Council.

Institutional Review Board Statement: The study was conducted according to the guidelines of the Declaration of Helsinki and approved by the Institutional Review Board of the Ningbo Poly technic (30 July 2021).

Informed Consent Statement: Informed consent was obtained from all subjects involved in the study. 
Data Availability Statement: Data sharing not applicable.

Conflicts of Interest: The authors declare no conflict of interest. The funders had no role in the design of the study; in the collection, analyses, or interpretation of data; in the writing of the manuscript, or in the decision to publish the results.

\section{References}

1. Beeton, S. Film-Induced Tourism, 2nd ed.; Channel View: Bristol, UK, 2016.

2. Kim, S.S.; Kim, S.S.; Petrick, J.F. The effect of film nostalgia on involvement, familiarity, and behavioral intentions. J. Travel Res. 2019, 58, 283-297. [CrossRef]

3. Gong, T.; Tung, V.W.S. The impact of tourism mini-movies on destination image: The influence of travel motivation and advertising disclosure. J. Travel Tour. Mark. 2017, 34, 416-428. [CrossRef]

4. Kim, S.S.; Kim, S.S. Segmentation of potential film tourists by film nostalgia and preferred film tourism program. J. Travel Tour. Mark. 2018, 35, 285-305. [CrossRef]

5. Hahm, J.; Wang, Y. Film-Induced Tourism as a Vehicle for Destination Marketing: Is it Worth the Efforts? J. Travel Tour. Mark. 2011, 28, 165-179. [CrossRef]

6. Kirillova, K.; Peng, C.; Chen, H. Anime consumer motivation for anime tourism and how to harness it. J. Travel Tour. Mark. 2019, 36, 268-281. [CrossRef]

7. Seaton, P.A.; Yamamura, T. Japanese Popular Culture and Contents Tourism; Routledge: London, UK, 2019.

8. Connell, J.; Meyer, D. Balamory revisited: An evaluation of the screen tourism destination-tourist nexus. Tour. Manag. 2009, 30, 194-207. [CrossRef]

9. O'Connor, N.; Flanagan, S.; Gilbert, D. The use of film in re-imaging a tourism destination: A case study of Yorkshire, UK. J. Vacat. Mark. 2010, 16, 61-74. [CrossRef]

10. Hudson, S.; Wang, Y.; Gil, S.M. The influence of a film on destination image and the desire to travel: A cross-cultural comparison. Int. J. Tour. Res. 2011, 13, 177-190. [CrossRef]

11. Kim, S.; Long, P.; Robinson, M. Small Screen, Big Tourism: The Role of Popular Korean Television Dramas in South Korean Tourism. Tour. Geogr. 2009, 11, 308-333. [CrossRef]

12. Rattanaphinanchai, S.; Rittichainuwat, B.N. Film-Induced tourism in Thailand: An influence of international tourists' intention to visit film shooting location. Int. J. Tour. Sci. 2018, 18, 325-332. [CrossRef]

13. Qiao, F.; Choi, Y.; Lee, T. Assessing feasibility of film-induced tourism: The case of Singapore. Int. J. Tour. Sci. 2016, 16, 93-105. [CrossRef]

14. Soliman, D.M. Exploring the role of film in promoting domestic tourism: A case study of Al Fayoum, Egypt. J. Vacat. Mark. 2011, 17, 225-235. [CrossRef]

15. Butler, R.W. The Influence of the Media in Shaping International Tourist Patterns. Tour. Recreat. Res. 1990, 15, 46-53. [CrossRef]

16. Volo, S.; Irimias, A.R. Film Tourism and Post-Release Marketing Initiatives: A Longitudinal Case Study. J. Travel Tour. Mark. 2015, 33, 1071-1087. [CrossRef]

17. Iwashita, C. Roles of Films and Television Dramas in International Tourism: The Case of Japanese Tourists to the UK. J. Travel Tour. Mark. 2008, 24, 139-151. [CrossRef]

18. Kim, S.S.; Kim, S.S.; King, B. Nostalgia film tourism and its potential for destination development. J. Travel Tour. Mark. 2019, 36, 236-252. [CrossRef]

19. Lopez, L.; Nicosia, E.; González, R.C.L. Sustainable Tourism: A Hidden Theory of the Cinematic Image? A Theoretical and Visual Analysis of the Way of St. James. Sustainability 2018, 10, 3649. [CrossRef]

20. Pérez García, Á.; Rodríguez, I.S.; Melgarejo, A.M. The Development of the Competency of "Cultural Awareness and Expressions" Using Movie-Induced Tourism as a Didactic Resource. Educ. Sci. 2021, 11, 315. [CrossRef]

21. Sohn, D.; Youn, S.H. Fundamental sources and sustainable development of the Korean cultural entertainment industry with the Korean wave. Int. J. Tour. Sci. 2016, 16, 83-92. [CrossRef]

22. Chua, B.H.; Iwabuchi, K. East Asian Pop Culture: Analysing the Korean Wave; Hong Kong University Press: Hong Kong, China, 2008.

23. Dolnicar, S.; Grün, B. Validly Measuring Destination Image in Survey Studies. J. Travel Res. 2012, 52, 3-14. [CrossRef]

24. Tasci, A.D.; Gartner, W.C. Destination Image and Its Functional Relationships. J. Travel Res. 2007, 45, 413-425. [CrossRef]

25. Im, H.H.; Chon, K. An exploratory study of movie-induced tourism: A case of the movie The Sound of Music and its locations in Salzburg, Austria. J. Travel Tour. Mark. 2008, 24, 229-238. [CrossRef]

26. Li, S.; Li, H.; Song, H.; Lundberg, C.; Shen, S. The economic impact of on-screen tourism: The case of The Lord of the Rings and the Hobbit. Tour. Manag. 2017, 60, 177-187. [CrossRef]

27. Law, L.; Bunnell, T.; Ong, C.-E. The Beach, the gaze and film tourism. Tour. Stud. 2007, 7, 141-164. [CrossRef]

28. Donald, S.; Gammack, J.G. Tourism and the Branded City: Film and Identity on the Pacific Rim; Ashgate Publishing: Aldershot, UK, 2007.

29. Croy, W.G.; Walker, R.D. Rural Tourism and Film-Issues for Strategic Regional Development. In New Directions in Rural Tourism; Hall, D., Roberts, L., Mitchell, M., Eds.; Ashgate Publishing: Aldershot, UK, 2003. 
30. Kim, S.S.; Agrusa, J.; Lee, H.; Chon, K. Effects of Korean TV dramas on the flow of Japanese tourists. Tour. Manag. 2007, 28, 1340-1353. [CrossRef]

31. Busby, G.; Klug, J. Movie-induced tourism: The challenge of measurement and other issues. J. Vacat. Mark. 2001, 7, 316-332. [CrossRef]

32. Connell, J. Toddlers, tourism and Tobermory: Destination marketing issues and television-induced tourism. Tour. Manag. 2005, 26, 763-776. [CrossRef]

33. Riley, R.; Baker, D.; Van Doren, C.S. Movie induced tourism. Ann. Tour. Res. 1998, 25, 919-935. [CrossRef]

34. Cohen, E. The beach of 'the beach': The politics of environmental damage in Thailand. Tour. Recreat. Res. 2005, 30, 1-17. [CrossRef]

35. Iordanova, E.; Stylidis, D. The impact of visitors' experience intensity on in-situ destination image formation. Tour. Rev. 2019, 74, 841-860. [CrossRef]

36. Hosany, S.; Ekinci, Y.; Uysal, M. Destination image and destination personality: An application of branding theories to tourism places. J. Bus. Res. 2006, 59, 638-642. [CrossRef]

37. Bolan, P.; Williams, L. The role of image in service promotion: Focusing on the influence of film on consumer choice within tourism. Int. J. Consum. Stud. 2008, 32, 382-390. [CrossRef]

38. Pike, S.D.; Ryan, C.A. Destination Positioning Analysis through a Comparison of Cognitive, Affective, and Conative Perceptions. J. Travel Res. 2004, 42, 333-342. [CrossRef]

39. Gunn, C. Vacationscape: Developing Tourist Areas, 2nd ed.; Taylor \& Francis: Washington, DC, USA, 1997.

40. Stylidis, D. Residents' destination image: A perspective article. Tour. Rev. 2020, 75, 228-231. [CrossRef]

41. Kim, S.; Lehto, X.; Kandampully, J.; Leht, X. The role of familiarity in consumer destination image formation. Tour. Rev. 2019, 74, 885-901. [CrossRef]

42. Kotler, P. Marketing Management, 13th ed.; Prentice Hall: New York, NY, USA, 2009.

43. Young, A.F.; Young, R. Measuring the Effects of Film and Television on Tourism to Screen Locations: A Theoretical and Empirical Perspective. J. Travel Tour. Mark. 2008, 24, 195-212. [CrossRef]

44. Yamamura, T.; Seaton, P. Contents Tourism and Pop Culture Fandom: Transnational Tourist Experiences; Blue Ridge Summit; Channel View: Bristol, UK, 2020. [CrossRef]

45. Agarwal, S.; Shaw, G. Heritage, Screen and Literary Tourism; Blue Ridge Summit; Channel View: Bristol, UK, 2017. [CrossRef]

46. Li, X.; Kim, J.; Lee, T. Collaboration for Community-Based Cultural Sustainability in Island Tourism Development: A Case in Korea. Sustainability 2021, 13, 7306. [CrossRef]

47. Oh, M.-J.; Lee, T.J. How Local Festivals Affect the Destination Choice of Tourists. Event Manag. 2012, 16, 1-9. [CrossRef]

48. Park, S.; Chung, N.; Lee, W. Preserving the Culture of Jeju Haenyeo (Women Divers) as a Sustainable Tourism Resource. Sustainability 2020, 12, 10564. [CrossRef]

49. Korea Tourism Organization. Annual Report of Tourism Industry in Korea. 2017. Available online: http:/ / english.visitkorea.or. $\mathrm{kr} /$ mapInfo.kto?func_name=depth2\&md=enu\&lang_se=ENG\&area_code=39 (accessed on 5 May 2017).

50. Roman, M.; Niedziółka, A.; Krasnodębski, A. Respondents' Involvement in Tourist Activities at the Time of the COVID-19 Pandemic. Sustainability 2020, 12, 9610. [CrossRef]

51. Williams, N.L.; Wassler, P.; Ferdinand, N. Tourism and the COVID-(Mis)infodemic. J. Travel Res. 2020. [CrossRef]

52. Wahl, J.; Lee, S.; Jamal, T. Indigenous Heritage Tourism Development in a (Post-) COVID World: Towards Social Justice at Little Bighorn Battlefield National Monument, USA. Sustainability 2020, 12, 9484. [CrossRef]

53. Pallant, J. SPSS Survival Manual: A Step by Step Guide to Data Analysis Using SPSS for Windows, 3rd ed.; McGraw-Hill: Berkshire, UK, 2007.

54. Saunders, M.; Lewis, P.; Thornhill, A. Research Methods for Business Students, 5th ed.; FT-Prentice Hall: Harlow, UK, 2009. 